\title{
PRODUCTIVE CHARACTERISATION OF A GOAT BREED: STUDY OF GROWTH AND CSN1S1 GENE POLYMORPHISM
}

\author{
CARACTERIZACIÓNPRODUCTIVA DE UNARAZA CAPRINA: \\ ESTUDIO DEL CRECIMIENTO Y POLIMORFISMO DEL GEN CSN1S1
}

\author{
Vidilla, M. ${ }^{1}$, Ferrando, A. ${ }^{2}$, Villalba, D. ${ }^{1}$ and Jordana, J. ${ }^{2 *}$ \\ ${ }^{1}$ Departament de Producció Animal. Universitat de Lleida. Lleida. Spain. \\ ${ }^{2}$ Departament de Ciència Animal i dels Aliments. Facultat de Veterinària. Universitat Autònoma de \\ Barcelona. Bellaterra. Barcelona. Spain. *Jordi.Jordana@uab.cat
}

\section{AdDitiOnAL KEYWORDS \\ Conservation. Blanca de Rasquera.}

\section{SUMMARY}

The results of the productive characterisation of the Blanca de Rasquera goat meat breed are presented within the framework of a Conservation Programme. The 125 animals included in the study were randomly chosen from among six farms under an extensive production system and natural lactation. The growth of kids was characterised by quantifying body weight from birth to slaughter. The influence of sex and type of birth on growth was evaluated. Kids showed a good growth rate (123 g/day on average for the period 0-45 days), comparable to, or slightly lower than, other Spanish autochthonous meat breeds. As expected, the type of birth and sex significantly influenced weight and the growth of kids.

A random sample of 36 individuals was analysed in relation to the $\alpha_{S 1}$-casein gene (CSN1S1). A greater frequency $(62.5 \%)$ was found for alleles associated with high $\alpha_{S 1}$-casein quantity in milk, indicating its good potential and technological quality for cheese production.

\section{RESUMEN}

En el marco de un Programa de Conservación, se presentan los resultados de la caracterización productiva de la raza caprina Blanca de Rasquera, de aptitud cárnica. Se estudiaron un total de 125 animales escogidos de forma aleatoria y distribuidos en 6 explotaciones de régimen extensivo y lactancia natural. Se caracterizó el crecimiento de los cabritos mediante la cuantificación de los

Recibido: 27-10-10. Aceptado: 13-4-11.

\author{
Palabras clave adicionales \\ Conservación. Blanca de Rasquera.
}

pesos desde el nacimiento hasta el sacrificio. Se evaluó la influencia del sexo y tipo de parto sobre el crecimiento. Los cabritos presentaron una buena tasa de crecimiento (123 g/día como promedio, para el período 0-45 días de edad), comparable, o ligeramente inferior, a otras razas cárnicas autóctonas españolas. Como era esperable, el tipo de nacimiento y el sexo influyeron de forma significativa en el peso y el crecimiento de los cabritos.

Se analizó una muestra aleatoria de 36 individuos, en relación al gen de la $\alpha_{\mathrm{S} 1}$-caseína (CSN1S1). Las mayores frecuencias alélicas $(62,5 \%)$ se encontraron para los alelos asociados con una elevada cantidad de $\alpha_{\mathrm{s} 1}$-caseína en la leche, indicando dichos resultados las buenas aptitudes y cualidades tecnológicas de su leche para la producción de quesos.

\section{INTRODUCTION}

The Blanca de Rasquera breed is the last redoubt of the indigenous genetic heritage of goats in Catalonia (Spain) (Parés et al., 2005). Considering their morphology and similarity to the Blanca Celtibérica breed, the group would include descendants of the Capra prisca. In recent decades the census has declined sharply, from 30000 individuals in 1995, to fewer than 5000 at the present time, which are spread over 18 farms (12 that 
own pure individuals and 6 mixed). The high average farmers age, together with a low guarantee of generational shift, has put the breed in danger of extinction (Carné et al., $2007 \mathrm{a}, \mathrm{b})$. The breed is currently classified in this category by the FAO (http:// dad.fao.org).

As part of the breed's Conservation Programme, which was started in 2003 by the Catalan Government's Department of Agriculture, Food and Rural Action (DAR), in collaboration with the Autonomous University of Barcelona (UAB), we present here the results of the productive characterisation of this meat breed, the main production of which is from 50 days-old kids weighing approximately $8.5 \mathrm{~kg}$. Additionally, a few farms produce ricotta and fresh cheese, primarily for home consumption and some retail. There is a well known direct relationship between the different variants of the $\alpha_{\mathrm{S} 1}$-casein gene (CSN1S1) and the composition and technological properties of milk (Grosclaude et al., 1987; Caravaca et al., 2009). Therefore, the characterisation of the allelic distribution of the gene in the population may be of interest for the potential production and marketing of Blanca de Rasquera cheese. This work complements previous studies of the structural, morphological and genetic characterisation of this breed (Carné et al., 2007a, b; Jordana et al., 2007).

\section{MATERIALSANDMETHODS}

A total of 125 kids ( 67 males and 58 females) were chosen randomly and distributed on six farms, which are representative of $62 \%$ of the total census. All herds were exploited under an extensive production system, and kids were only breastfed (natural lactation) without any supplementary feeding. All farms used discontinuous and natural mating, with the majority reproductive rate of a birth per goat and year, preferably in the autumn. The growth of the kids (Average Daily Gain-ADG) was characterised by recording their weights from birth to slaughter, using a digital scale accurate to $50 \mathrm{~g}$. All records were taken in the morning, after the kids had been breastfed. Subsequently, we evaluated the factors influencing growth: sex (male or female) and type of birth (single or double).

Statistical analysis was performed using a mixed model with fixed effects (sex, farm and type of birth) and random effect (kid). Birth weight was considered as a covariate. Statistics were calculated using the MIXED procedure of SAS software, version 9.1 (SAS, 2004).

Additionally, we analysed a random sample of 36 individuals, from different herds, with the aim of genotyping alleles of the $\alpha_{\mathrm{S} 1}$-casein gene (CSN1S1) that are segregating in the population, following the methodology described by Caravaca et al. (2008).

\section{RESULTSANDDISCUSSION}

The results (table I) showed that the average weight at birth was $2.94 \pm 0.08 \mathrm{~kg}$ (similar values for males and females). The

Table I. Least squares means and standard errors of body weight ( $\mathrm{kg}$ ) from birth $(\mathrm{WB})$ to 63 days. (Valores medios y errores estándar de los pesos vivos, desde el nacimiento hasta los 63 días de edad).

\begin{tabular}{cccr}
\hline Age (days) & Males & Females & Global \\
\hline WB & $3.0 \pm 0.05$ & $2.9 \pm 0.06$ & $2.9 \pm 0.08$ \\
7 & $4.1 \pm 0.05^{\mathrm{a}}$ & $3.8 \pm 0.05^{\mathrm{b}}$ & $4.0 \pm 0.07$ \\
14 & $5.1 \pm 0.07^{\mathrm{a}}$ & $4.7 \pm 0.07^{\mathrm{b}}$ & $4.9 \pm 0.1$ \\
21 & $6.1 \pm 0.09^{\mathrm{a}}$ & $5.6 \pm 0.10^{\mathrm{b}}$ & $5.8 \pm 0.14$ \\
28 & $7.0 \pm 0.12^{\mathrm{a}}$ & $6.4 \pm 0.13^{\mathrm{b}}$ & $6.7 \pm 0.17$ \\
35 & $7.9 \pm 0.14^{\mathrm{a}}$ & $7.2 \pm 0.16^{\mathrm{b}}$ & $7.5 \pm 0.21$ \\
42 & $8.6 \pm 0.18$ & $7.9 \pm 0.19$ & $8.3 \pm 0.26$ \\
49 & $9.3 \pm 0.22$ & $8.7 \pm 0.23$ & $9.0 \pm 0.31$ \\
56 & $9.9 \pm 0.28$ & $9.4 \pm 0.29$ & $9.7 \pm 0.38$ \\
63 & $10.5 \pm 0.35$ & $10.0 \pm 0.35$ & $10.3 \pm 0.47$ \\
\hline
\end{tabular}

${ }^{\mathrm{ab} D i f f e r e n t ~ l e t t e r s ~ i n d i c a t e ~ s i g n i f i c a n t ~ d i f f e r e n c e s ~}$ between sexes at $p<0.05$. 
sex significantly influenced weight and growth of kids at the first weeks of the rearing period (table I and II). The daily weight gain $(\mathrm{g} / \mathrm{d})$ for all animals was $113 \mathrm{~g} /$ d on average: $135 \mathrm{~g} / \mathrm{d}$ during the first month and $95 \mathrm{~g} / \mathrm{d}$ during the second (table II). The weight at 42 days was $8.6 \pm 0.18 \mathrm{~kg}$ for males and $7.9 \pm 0.19 \mathrm{~kg}$ for females. The single birth presented significantly better performance (data not shown). However, this higher performance was only statistically significant $(p<0.05)$ for the average weight at the different controls (10 controls) throughout the rearing period (from birth to 63 days); ADG showed no statistical significant differences at any control. The prolificacy average obtained from the sample was 1.3 kids/goat. Although the data collected does not allow statistical analysis and cannot be extrapolated for the whole breed (it was only possible to obtain data from 13 animals from the same farm), we did note that the average weight of carcasses was $4.6 \mathrm{~kg}$ with a yield of $55 \%$. Blanca de Rasquera kids showed a relatively good growth rate (123 $\mathrm{g} / \mathrm{d}$ on average for the period 0-45 days), but slightly lower than other Spanish native meat breed (Vidilla, 2008). For instance, the Negra Serrana breed presented $145 \mathrm{~g} / \mathrm{d}$ on average for the same period (Alía, 1987). However, the growth rate was comparable to that of Blanca Andaluza breed that presented values of $114.2 \mathrm{~g} / \mathrm{d}$ for kids slaughtered at $9 \pm 2 \mathrm{~kg}$ of body weight (Germano Costa et al., 2005).

There are currently 18 known allelic variants associated with high, medium, low, and no CSN1S1 content in milk (Caravaca et al., 2008, 2009). The allelic frequencies obtained for the Blanca de Rasquera goat were as follows: $\operatorname{fr}(\mathrm{A})=0.153 ; \operatorname{fr}(\mathrm{B})=0.472$; fr $(E)=0.361$ and fr $(F)=0.014$. In most European breeds studied (Jordana et al., 1996; Sacchi et al., 2005), the most common alleles were those associated to lowintermediate content of CSN1S1 (mainly alleles E and F). However, different patterns have been found in some breeds such as
Table II. Evolution of average daily gain $(A D G)$ of weight $(g)$ of kids. (Evolución de la ganancia media diaria de peso (g) en los cabritos).

\begin{tabular}{lccc}
\hline & Males & Females & Global \\
\hline ADG 7 & $153 \pm 5.7^{\mathrm{a}}$ & $131 \pm 6.3^{\mathrm{b}}$ & $142 \pm 8.3$ \\
ADG 14 & $143 \pm 4.7^{\mathrm{a}}$ & $126 \pm 5.2^{\mathrm{b}}$ & $135 \pm 7.0$ \\
ADG 21 & $134 \pm 4.4$ & $121 \pm 4.8$ & $127 \pm 6.4$ \\
ADG 28 & $124 \pm 4.9$ & $116 \pm 5.1$ & $120 \pm 6.9$ \\
ADG 35 & $114 \pm 6.0$ & $111 \pm 6.0$ & $113 \pm 8.0$ \\
ADG 42 & $104 \pm 7.6$ & $106 \pm 7.4$ & $105 \pm 9.7$ \\
ADG 49 & $95 \pm 9.3$ & $101 \pm 8.9$ & $98 \pm 11.7$ \\
ADG 56 & $85 \pm 1.1$ & $96 \pm 10.7$ & $91 \pm 13.9$ \\
ADG 63 & $75 \pm 12.9$ & $91 \pm 12.5$ & $83 \pm 16.2$
\end{tabular}

${ }^{a b}$ Different letters indicate significant differences between sexes at $p<0.05$.

Palmera, Majorera and Tinerfeña (Canary Islands), in which alleles associated to high contents of CSN1S1 (mainly A, B and C) were above $60 \%$, as well as the Italian Garganica, Maltese and Jonica. In the Blanca de Rasquera goat high content alleles accounted for $62.5 \%$. Despite being a meat breed, the results indicate their milk presents good aptitudes and technological qualities for producing cheese. This favourable dairy potential was also contrasted on a morphological level (Carné et al., 2007b) by analysing several zoometric indices. Another important aspect for the breed could be its ancestral and phylogenetic slope, because, according to different authors (Grosclaude et al., 1987; Jordana et al., 1996) high content alleles represent ancestral sequences of this gene in goats, suggesting that the breed may have retained a high ancestral genetic variability.

\section{CONCLUSIONS}

As expected, the type of birth and sex significantly influenced weight and the growth of kids. The weights and growth were comparable, but slightly lower, than those obtained in other Spanish native meat 


\section{VIDILLA, FERRANDO, VILLALBA AND JORDANA}

breeds, so this population, despite being small, shows good potential for quality meat production. The implementation of a future selection programme opens a wide range of possibilities for genetic improvement of these characters.

Despite being a meat-oriented breed, the results of the analysis of the zoometric indices together with allele frequencies of the CSN1S1 gene (> 60\% of alleles associated with high protein content), reveal the

\section{BIBLIOGRAPHY}

Alía, M.J. 1987. Curva de crecimiento en cabritos de raza Negra Serrana. XII Jornadas Científicas de la Sociedad Española de Ovinotecnia y Caprinotecnia. Guadalajara. España. pp. 217225.

Caravaca, F., Amills, M., Jordana, J., Angiolillo, A., Agüera, P., Aranda, C., Menéndez-Buxadera A., Sánchez, A., Carrizosa, J., Urrutia, B., Sànchez A. and Serradilla, J.M. 2008. Effect of $\alpha_{S 1}$-casein (CSN1S1) genotype on milk CSN1S1 content in Malagueña and Murciano-Granadina goats. J. Dairy Res., 75: 481-484.

Caravaca, F., Carrizosa, J., Urrutia, B., Baena, F., Jordana, J., Amills, M., Badaoui, B., Sánchez, A., Angiolillo, A. and Serradilla, J.M. 2009. Effect of $\alpha_{S 1}$-casein (CSN1S1) and $\kappa$-casein (CSN3) genotypes on milk composition in MurcianoGranadina goats. J. Dairy Sci., 92: 2960-2964.

Carné, S., Roig, N. y Jordana, J. 2007a. La Cabra Blanca de Rasquera: caracterización estructural de las explotaciones. Arch. Zootec., 56: 4354.

Carné, S., Roig, N. y Jordana, J. 2007b. La Cabra Blanca de Rasquera: caracterización morfométrica y faneróptica. Arch. Zootec., 56: 319-330.

Germano Costa, R., Sanz Toro, B., Camacho Vallejo, M.E. y Argüello Henríquez, A. 2005 Resultados comparativos de crecimiento de cabritos de las razas Murciano-Granadina y Blanca Andaluza, en lactancia natural. Efectos de la raza, del sexo y del sistema de producción. VI Simposio Iberoamericano sobre Conservación y Utilización de Recursos Zoogenéticos. good potential and technological quality of their milk for cheese production.

\section{ACKNOWLEDGMENTS}

This work has been supported by the Department of Agriculture, Food and Rural Action (DAR) of the Government of Catalonia. We also thank the DAR Regional Office of the Ribera d'Ebre and all breeders for their collaboration.

San Cristóbal de las Casas. Chiapas. México. Memorias, 215-217.

Grosclaude, F., Mahé, M.F., Brignon, G., Di Stasio, L. and Juenet, R. 1987. A Mendelian polymorphism underlying quantitative variation of goat $\alpha_{\mathrm{S1}}$-casein. Genet. Sel. Evol., 19: 399-412.

Jordana, J., Amills, M., Díaz, E., Angulo, C., Serradilla, J.M. and Sànchez, A. 1996. Gene frequencies of caprine $\alpha_{\mathrm{s} 1}$-casein polymorphism in Spanish goat breeds. Small Ruminant Res., 20: 215221.

Jordana, J., Marmi, J., Carné, S. y Ferrando, A. 2007. Caracterización genética del último reducto caprino autóctono de Catalunya: la cabra Blanca de Rasquera. VIII Simposio Iberoamericano sobre Conservación y Utilización de Recursos Zoogenéticos. Quevedo. Ecuador. Memorias (Póster), 149-154.

Parés, P.M., Francesch, A., Jordana, J. i Such, X. 2005. Catalans de Pèl i Ploma. Races Domèstiques Autòctones de Catalunya. Lynx Edicions. Bellaterra. Barcelona. Spain. pp. 282. Sacchi, P., Chessa, S., Budelli, E., Bolla, P., Ceriotti, G., Soglia, D., Rasero, R., Cauvin, E. and Caroli, A. 2005. Casein haplotype structure in five Italian goat breeds. J. Dairy Sci., 88: 1561-1568. SAS. 2004. SAS Institute Inc. SAS® 9.1.2. Qualification Tools User's Guide. Cary, NC, USA.

Vidilla, M. 2008. Caracterització del creixement dels cabrits de cabra Blanca de Rasquera. Treball Pràctic Tutorat. ETSEA. Universitat de Lleida. Spain. pp. 62. 